\title{
Study of Ethnoscience for Making Dodol Kentang (Potatoes jam) as a Learning Media
}

\author{
Indah Kencanawati ${ }^{1}$ \\ $\left\{\right.$ kencanawatiindah@gmail.com $\left.{ }^{1}\right\}$
}

\begin{abstract}
Student of Doctoral Program of Mathematics and Science Education Universitas Jambi ${ }^{1}$ Lecturer of Biology Education, Faculty of Education and Teacher Training of IAIN Kerinci ${ }^{1}$
\end{abstract}

\begin{abstract}
Kerinci has fertile land for seasonal crops such as potatoeses (Solanum tuberosum. L). One of the varieties of potatoes that is widely consumed and utilized by the local community is the Granola variety, because it is easy to grow and has a soft texture. Not only used as vegetables, local people also use this as one of ingredients to make Dodol Kentang (Potatoes jam) as snacks. The process of making Dodol Kentang (Potatoes jam) is used as a learning media for biology by reconstructing indigenous knowledge (indigeneous science) into knowledge of scientific reconstruction (scientific knowledge). The study was conducted with a qualitative based ethnoscience in the village of Lubuk Nagodang, Siulak, Kerinci district, Jambi Province. There are three stages in conducting the study, namely observation, interviews and documentation. The reconstruction process focused on community activities in making dodol kentang (Potatoes jam) and was associated with applied biology. The results showed that making dodol kentang (Potatoes jam) is still traditional and hereditary, the use of abundant natural resources of potatoeses is processed into snacks as a snack with various flavors such as pandan flavor, strawberry flavor, pineapple flavor, palm sugar flavor, red bean flavor, taste durian and purple sweet potatoes flavor.
\end{abstract}

Keywords: Ethnoscience, Dodol Kentang (Potatoes jam), Learning Media.

\section{Introduction}

Education plays a very important role in improving human resources. In the process of improving education, a learning process that supports it is also needed. Instructional models in applied biology is inquiry model. Inquiri means of learning activities that involve maximally all students abilities to search and investigate systematically, critically, logically, and analytically, so that they are confidence in formulating their own findings (Gulo, 2004). Inquiry model in biology has been developed and used for all of students, students learn content, processes with a scientific approach and the mentoring process carried out by lecturers / teachers towards students during the studying. Good lecturers / teachers must be able to teach how to learn, how to remember, how to think, and how to motivate themselves.

Applied biology maked students are expected to be able to understand the environment and further development in daily life. Giving direct experience can be obtained from inquiry / investigation or experiment as part of scientific performance based on scientific attitude. The learning process is a factor that can influence students to reach the skills demanded for the future. Ideal learning if the lecturer is able to develop his learning plan with activities that challenge students to practice critical thinking, be able to solve problems, collaborate with 
group members, and be able to convey their ideas (Wulandari, Amin, Zubaidah, \& Mimien Henie, 2018).

Learning of applied biology consept, can be done by showing its application to phenomena in daily life such as making Dodol Kentang (potatoes jam). In this case, students are still not used to applying material that has been received with direct practice in daily life, because it is necessary to teach learning using environmental and cultural concepts as learning resources. Learning that uses cultural concepts as learning resources and learning media can improve students' ability to use science/ biology knowledge.

The scientific approach suggested in education of Indonesia today is ethnics, namely indigenous knowledge in the form of language, customs and culture, morals, as technologies created by certain people or people containing scientific knowledge (Sudarmin, 2015). This approach is a strategy for creating a learning environment for ethnics and learning planning that integrates culture as part of the science/biology learning process. The application of science teaching and learning with an ethnoscience approach requires the ability of lecturers / teachers to combine original knowledge with scientific knowledge (Sarfiyo \& Pannen 2015).

The word ethnoscience (ethnoscience) derives from the word ethnos (Greek) which means nation, and scientia (Latin) means knowledge. Therefore ethnoscience is the knowledge possessed by a nation or more precisely a particular ethnic group or social group as a typical system of knowledge and cognition of a givel culture. The main objective is the emphasis on the system or device of knowledge which is a unique knowledge of a society because it is different from other communities (Parmin, 2017).

An important factor that influences education in creating meaningful learning is by reconstructing the knowledge of previous students. In daily life students always interact in the environment and regional culture, it can increase the potential of students' understanding of learning, especially biology learning which is developed from the perspective of local culture and organized local wisdom related to certain natural events (Ethnoscience).

In addition, through ethnic / cultural based learning, students will make observations on making dodol kentang (Potatoes jam) directly so that students can identify scientific questions, explain phenomena scientifically and draw conclusions regarding changes that occur in applied biology events and apply changes that occur through making dodol kentang (Potatoes jam) .

Direct student involvement in making dodol kentang (Potatoes jam) provides a direct experience of the process of making dodol kentang (Potatoes jam) which is an application of the applied biology. The active involvement of students in the learning process will bring out the values instilled through life experiences to the environment. So that lecturers not only submit applied biology theory but also can transfer the values obtained from the learning activities that have been done. Learning done outside of observation can train students to find their own concepts that are related to existing concepts. This will help students to improve students 'abilities in terms of content, context and student science competencies or students' scientific literacy skills and train students to think critically about the observed phenomena.

Another supporting element in the learning process is the use of learning media. The media is the delivery of messages from the sender to the recipient of the message, thus the media is a vehicle for channeling learning information or channeling messages (Rusman, 2013).

The National Education Association (NEA) states that media are both printed and audiovisual forms of communication and equipment. The media should be manipulated, can be seen, heard and read (Arief Sadiman, et al, 2012). 
Learning media is used as a means of learning in schools aimed at improving the quality of education. Media is a means that can be used as an intermediary that is useful to improve effectiveness and efficiency in achieving goals (Rusman, et al, 2013).

Levie and Lentz put forward four functions of learning media, especially visual media, namely:

a. The function of visual media attention is the core, which is to make students concentrate and attract to the lesson.

b. The affective function of visual media can be seen from the students' enjoyment when learning (or reading) the pictorial text.

c. The cognitive function of visual media can be seen from research findings which reveal that visual symbols or images facilitate the achievement of goals to understand and remember or the messages contained in the images.

d. Compensatory function of learning media can be seen from the results of research that visual media that provides context to understand the text helps students who are weak in reading to organize information in the text and recall it (Arsyad, 2013).

Learning is done by observing phenomena in social life and reconstructing it as scientific science, one of which has been carried out in Kerinci, Jambi Province. Kerinci district not only presents beautiful natural scenery and mountains but also has fertile land for planting various kinds of plants (Wiseza, 2016). One of the plants that is used is potato (Solanum tuberosum L) which is called "kubic" in the local language. Potatoes are recognized by people as staple foods abroad. This is because potatoes contain carbohydrates. In Indonesia, potatoes are still considered a luxury vegetable. However, potatoes are good food and very nutritious (Sunarjoyo, 2015). Potatoes also contain a number of vitamin A, B-complex, C, to folic acid and contain minerals, proteins, carbohydrates and polyphenols.

The surrounding community has used this potato to be a productive process besides being consumed in everyday life (Apdelmi, 2018). The amount of potatoes that many have used by the community as snacks and souvenirs for outsiders and tourists who come to see the process of making dodol kentang (Potatoes jam). The selected potato is granola variety which has a soft texture. Actually dodol kentang (Potatoes jam) is not a typical kerinci food, but with empowerment carried out by the regional government through the dodol kentang (Potatoes jam) industry service it became a special food of Kerinci district in the late 1990s.

The process of making dodol kentang (Potatoes jam) without them knowing it can be studied with science called ethnoscience. The process of ethnoscience is an effort to reconstruct indigenous knowledge (indigeneous science) into knowledge of scientific reconstruction (scientific knowledge). The process of making dodol kentang (Potatoes jam) is related to the biological science that underlies the process of making dodol kentang (Potatoes jam), which is the subject of applied biology.

Learning science that pays attention to the wisdom of local culture as national identity, the character and customs of local culture in the era of learning ethnically related. Ethnographic learning is very important in Indonesia because Indonesia consists of various ethnic groups and various cultures that must be preserved (Sudarmin, 2015). For this reason there must be a special study that can document and identify ethnics activities in the process of making dodol kentang (Potatoes jam) in motivating and increasing knowledge of inquiry students in the subject of applied biology. 


\section{Material And Methods}

The study was conducted with a qualitative based ethnoscience in the village of Lubuk Nagodang, Siulak, Kerinci district, Jambi Province. There are three stages in conducting the study, namely observation, interviews and documentation. The reconstruction process is focused on community activities in making dodol potatoes and is associated with applied biology. Data retrieval includes primary data collected through observation and interview techniques while secondary data with literature and document studies. To ensure the level of trust in data is carried out in several ways, it is necessary to conduct intensive observations, data triangulation and methods and prepare references. Qualitative analysis is done by describing people's knowledge about making dodol kentang (Potatoes jam) in daily life and in community life. (Parmin, 2017).

The study have started with observation, interviews and documentation. The reconstruction process focused on community activities in making dodol kentang (Potatoes jam) and was associated with biology applied. Data retrieval includes primary data collected through observation and interview techniques while secondary data with literature and document studies. To ensure the level of trust in the data is done in several ways, namely conducting intensive observation, data triangulation and methods and preparing references. Qualitative analysis is done by describing people's knowledge about making dodol kentang (Potatoes jam) in daily life and in community life.

\section{Results And Discussion}

Based on the results of observations and interviews with the community in the village of Lubuk Nanggodang obtained information that making dodol kentang (Potatoes jam) is still done traditionally and for generations, the utilization of natural resources of potatoes is abundantly processed into snacks as a snack with various flavors such as pandan flavor, strawberry flavor, taste pineapple, the taste of palm sugar, red bean flavor, durian flavor to purple sweet potato flavor.

Learning that is done by observation aims to invite students to recognize objects, symptoms and problems, examine these problems and then find conclusions on the concept of making dodol kentang (Potatoes jam) they learned. The conceptualization and understanding obtained by students is not directly from the lecturer but is obtained from the surrounding community. By exploring and observing the environment, students will interact with facts in the environment so that they find experience and something that raises questions and problems (Hadi \& Ahid, 2017). The environment referred to is not only the physical environment, but also includes the social, cultural and technological environment.

Observation activities encourage students to actively explore the surrounding environment as a learning medium to achieve cognitive, affective and psychomotor skills. which causes students to have mastery of knowledge and skills in mastery of work, mastery of addressing and mastery of society, so that the use of the environment as a learning medium is very supportive in studying biology, especially applied biology. 
Table 1. Results of Community Knowledge Reconciliation into Scientific Knowledge

\begin{tabular}{|c|c|c|c|}
\hline No & Question & Community Knowledge & Scientific Knowledge \\
\hline 1 & What is potato? & $\begin{array}{l}\text { Potatoes are a type of } \\
\text { vegetable commonly } \\
\text { consumed with rice, local } \\
\text { people said "kubik". }\end{array}$ & $\begin{array}{l}\text { Potatoes (Solanum tuberosum } \\
\text { L.) are plants from the } \\
\text { Solanaceae tribe which have } \\
\text { edible stem tubers called } \\
\text { "potatoes". } \\
\text { Science concept : various kinds } \\
\text { of plants }\end{array}$ \\
\hline 2 & $\begin{array}{l}\text { What are the potatoes } \\
\text { used in daily life? }\end{array}$ & $\begin{array}{l}\text { Potatoes are used as } \\
\text { vegetables, food mixes and } \\
\text { appetite enhancers }\end{array}$ & $\begin{array}{l}\text { Utilization of potatoes because } \\
\text { of the carbohydrate content of } \\
20 \% \text { is mixed in vegetables, as } \\
\text { a snack and staple food instead } \\
\text { of rice, especially for diabetics. } \\
\text { Science concept : nutrient } \\
\text { content in potatoes }\end{array}$ \\
\hline 3 & $\begin{array}{l}\text { What are the kind of } \\
\text { potatoes? }\end{array}$ & $\begin{array}{l}\text { Granola and Cipanas } \\
\text { potatoes, have yellow skin } \\
\text { and white flesh, there are also } \\
\text { red potatoes. }\end{array}$ & $\begin{array}{l}\text { Potatoes can be classified } \\
\text { according to the color of the } \\
\text { tuber, namely yellow potatoes, } \\
\text { white potatoes, and red } \\
\text { potatoes. White skinned and } \\
\text { white fleshy potatoes. Varieties } \\
\text { including white potatoes are } \\
\text { Granola, Donata, Radosa, and } \\
\text { Sebago. Other potatoes are red } \\
\text { potatoes whose skin is red, but } \\
\text { the flesh is yellow. Varieties } \\
\text { which include red potatoes are } \\
\text { Desiree, Arka, and Red pontiac. } \\
\text { Science concept : Morphology } \\
\text { and Taxonomy of potatoes }\end{array}$ \\
\hline 4 & $\begin{array}{l}\text { What kind of potatoes } \\
\text { are used in making } \\
\text { dodol kentang (Potatoes } \\
\text { jam)? }\end{array}$ & Granola variety & $\begin{array}{l}\text { One of potato in Kerinci district } \\
\text { used in making dodol kentang is } \\
\text { the Granola Potato, because it } \\
\text { has yellow-white bulb color, } \\
\text { has a soft texture and has a } \\
\text { carbohydrate content of up to } \\
20 \% \\
\text { Science concept : Useful plants } \\
\text { by local people }\end{array}$ \\
\hline 5 & $\begin{array}{l}\text { What are the tools } \\
\text { needed for making dodol } \\
\text { kentang (Potatoes jam)? }\end{array}$ & $\begin{array}{l}\text { Iron pots, fried spoons, } \\
\text { stoves, mold tools, filters, } \\
\text { basins, cutting boards and } \\
\text { drying racks }\end{array}$ & $\begin{array}{l}\text { The tools used are iron pots, } \\
\text { fried spoons, stoves, mold tools, } \\
\text { filters, basins, cutting boards } \\
\text { and drying racks } \\
\text { Science concept : Traditional } \\
\text { tools in applied biology }\end{array}$ \\
\hline 6 & $\begin{array}{l}\text { What are the ingredients } \\
\text { in making dodol kentang } \\
\text { (Potatoes jam)? }\end{array}$ & $\begin{array}{l}\text { Potatoes, coconut, sugar, } \\
\text { white glutinous flour, salt, } \\
\text { vanilla, etc. }\end{array}$ & $\begin{array}{l}\text { The ingredients include ten } \\
\text { kilos finely ground boiled } \\
\text { potatoes, grated ten grains, two } \\
\text { kilos of flour, eight kilos of } \\
\text { sugar, flavorings and salt and }\end{array}$ \\
\hline
\end{tabular}




\begin{tabular}{|c|c|c|c|}
\hline No & Question & Community Knowledge & Scientific Knowledge \\
\hline 7 & $\begin{array}{l}\text { What is the process of } \\
\text { making dodol kentang } \\
\text { (Potatoes jam)? }\end{array}$ & $\begin{array}{l}\text { The peeled potatoes are then } \\
\text { washed, the potatoes are } \\
\text { boiled until cooked, after } \\
\text { being cooked then the stew is } \\
\text { cooled, after a cold the } \\
\text { potatoes are ground until } \\
\text { smooth, add coconut milk, } \\
\text { white glutinous flour, vanilla, } \\
\text { sugar and salt until the } \\
\text { mixture is well mixed. The } \\
\text { thickened dough is lifted } \\
\text { from the furnace and poured } \\
\text { into the mold, flattened and } \\
\text { cooled for the printing and } \\
\text { cutting process according to } \\
\text { its size. After cold, the pieces } \\
\text { of dodol potatoes are dried in } \\
\text { the drying rack, after drying } \\
\text { the dodol kentang are ready } \\
\text { to he nacked }\end{array}$ & $\begin{array}{l}\text { taste. } \\
\text { Science concept : Ingredients } \\
\text { in making dodol kentang } \\
\text { The process of making dodol } \\
\text { kentang through several stages, } \\
\text { namely: } \\
\text { 1. Preparation } \\
\text { 2. Boiling } \\
\text { 3. Milling } \\
\text { 4. Mixing the dough } \\
\text { 5. Cooking } \\
\text { 6. Printing and cutting } \\
\text { 7. Drying } \\
\text { 8. Packaging using oil paper } \\
\text { Science concept : } \\
\text { Conventional/traditional } \\
\text { process in applied biology }\end{array}$ \\
\hline 8 & $\begin{array}{l}\text { How long does the } \\
\text { dodol kentang (Potatoes } \\
\text { jam) dry? }\end{array}$ & $\begin{array}{l}\text { Drying dodol potatoes } \\
\text { ranges from 2-3 days. }\end{array}$ & $\begin{array}{l}\text { The process of drying potato } \\
\text { dodol using sunlight for } 2-3 \\
\text { days is able to reduce excess } \\
\text { water content in potato } \\
\text { composition, if the weather } \\
\text { does not support the drying } \\
\text { process, it lasts for up to } 5 \text { days. } \\
\text { Science concept : the concept } \\
\text { of energy in making dodol } \\
\text { kentang }\end{array}$ \\
\hline 9 & $\begin{array}{l}\text { How long does dodol } \\
\text { kentang (Potatoes jam) } \\
\text { stand after it's packed? }\end{array}$ & $\begin{array}{l}\text { Dodol kentang can last one } \\
\text { to three months }\end{array}$ & $\begin{array}{l}\text { Dodol Kentang (Potatoes jam) } \\
\text { that has been packaged and } \\
\text { without preservatives can last } \\
\text { one to three months. } \\
\text { Science concept : Material } \\
\text { Sterilization without } \\
\text { preservatives }\end{array}$ \\
\hline 10 & $\begin{array}{l}\text { What are the flavor } \\
\text { variants of dodol } \\
\text { kentang (Potatoes jam)? }\end{array}$ & $\begin{array}{l}\text { Pandan flavor, strawberry } \\
\text { flavor, pineapple flavor, palm } \\
\text { sugar flavor, red bean flavor, } \\
\text { taste durian to purple sweet } \\
\text { potatoes flavor }\end{array}$ & $\begin{array}{l}\text { Pandan flavor, strawberry } \\
\text { flavor, pineapple flavor, palm } \\
\text { sugar flavor, red bean flavor, } \\
\text { taste durian to purple sweet } \\
\text { potatoes flavor } \\
\text { Science concept : Natural food } \\
\text { coloring }\end{array}$ \\
\hline
\end{tabular}


Table 2. The Relationship Between the Process of Making Dodol Kentang (Potatoes jam) and the Basic Competencies of Biology Student Inquiry

\begin{tabular}{|c|c|c|}
\hline No & Competency standards & $\begin{array}{c}\text { The Concept of Science in the Making } \\
\text { Process } \\
\text { Dodol Kentang (Potatoes jam) }\end{array}$ \\
\hline 1 & $\begin{array}{l}\text { Describe the kind of potato used in making } \\
\text { dodol kentang (Potatoes jam) }\end{array}$ & $\begin{array}{l}\text { There are several types of potatoes that can be } \\
\text { used in making dodol kentang, one of which is } \\
\text { potato Granola is one type of potato that is } \\
\text { widely found in Kerinci, has a yellow-white } \\
\text { tuber meat color, has a soft texture and has a } \\
\text { carbohydrate content of up to } 20 \%\end{array}$ \\
\hline 2 & $\begin{array}{l}\text { Explain the concept of applied biology in } \\
\text { making dodol kentang (Potatoes jam) }\end{array}$ & $\begin{array}{l}\text { The concept of biology applied for making } \\
\text { dodol kentang is conventional method from } \\
\text { preparation to packaging process in making } \\
\text { dodol kentang (Potatoes jam). }\end{array}$ \\
\hline 3 & $\begin{array}{l}\text { Analyze flavors in making dodol kentang } \\
\text { (Potatoes jam) }\end{array}$ & $\begin{array}{l}\text { Flavor variants in making dodol kentang use } \\
\text { food coloring that is safe to consume, namely } \\
\text { pandan flavor, strawberry flavor, pineapple } \\
\text { flavor, palm sugar flavor, red bean flavor, durian } \\
\text { flavor and purple sweet potato flavor. }\end{array}$ \\
\hline
\end{tabular}

\section{Conclusions}

The result concluded : Community knowledge with existing scientific concepts is expected as source of learning media for students in exploring and motivating inquiry knowledge in applied biology. Conceptualization and understanding obtained by students through field observations in making dodol kentang (Potatoes jam) improved students active in exploring their skills. Lecturers are expected to be able to correlate between community knowledge with existing scientific / biological concepts, so that the learning process is more active, creative and meaningful. Suggestions for further research are to explore the existing traditions and culture in Kerinci district to be constructed into scientific knowledge and utilized in the learning process.

\section{References}

[1] Arief Sadiman, dkk,: Media Pendidikan. PT. Raja Grafindo Persada, Jakarta (2012)

[2] Apdelmi.: Perkembangan industri dodol kentang ditinjau dari Perspektif sejarah: studi kasus di kecamatan siulak Kabupaten kerinci. Titian: Jurnal Ilmu Humaniora, Volume 2, No. 1, ( https://online-journal.unja.ac.id/index.php/titian). (2018)

[3] Azhar Arsyad,: Media Pembelajaran. PT. RajaGrafindo Persada, Jakarta (2013)

[4] Gulo. W.: Strategi Belajar Mengajar. PT Gramedia Widiasarana, Jakarta (2004)

[5] Hadi Puspita Wiwin, Mochammad Ahied.: Kajian Etnosains Madura dalam Proses Produksi Garam Sebagai Media Pembelajaran IPA Terpadu. Jurnal Ilmiah REKAYASA, Volume 10 No 2, Hlm. 79-86. (2017) 
[6] Rusman, Deni Kurniawan dan Cepi Riyana,: 169. Pembelajaran Berbasis Teknologi Informasi dan Komunikasi. Raja Grafindo Persada. Jakarta (2013)

[7] Rusman, Deni Kurniawan dan Cepi Riyana,: Op. Cith 171

[8] Sudarmin \& Pujiastuti, E.: Scientific Knowledge Based Culture and Local Wisdom in Karimunjawa for Growing Soft Skills Conservation International Journal of Science and Research Vol. 4, pp. 598-604. (2015)

[9] Sudarmin.: Pendidikan Karakter, Etnosains Dan Kearifan Lokal: KONSEP Dan Penerapannya hearts Penelitian Dan Pembelajaran Sains [ Pendidikan Karakter, ethnoscience dan Kearifan Lokal: Konsep dan Aplikasi dalam Penelitian dan Ilmu Pendidikan Karakter Pendidikan: Etnosains dan Kearifan Lokal] . FMIPA-Semarang: CV. Swadaya Manunggal, ISBN 978602-1034-00-2. (2016)

[10] Parmin,: Ethnosains. Swadaya Manunggal, Semarang (2016)

[11] Wiseza, C F.: Bauran pemasaran home industri olahan dodol kentang di desa lubuk nanggodang kabupaten kerinci. Jurnal Nur El-Islam, Volume 3 Nomor 2 (2016)

[12] Wulandari, T. S., Amin, M., Zubaidah, S., \& Mimien Henie, I.: Implementasi Keterampilan Berfikir Kritis Dosen Biologi di Universitas. Prosiding Seminar Nasional Biologi/IPA dan Pembelajarannya. pp. 1093-1100. (2018) 